\title{
Analysis of the dinoflagellate cyst genus Impletosphaeridium as a marker of sea- ice conditions off Seymour Island: An ecomorphological approach
}

\author{
S. Warny, ${ }^{1}$ J. B. Anderson, ${ }^{2}$ L. Londeix, ${ }^{3}$ and P. J. Bart ${ }^{4}$ \\ ${ }^{1}$ Museum of Natural Science, Louisiana State University, Foster Hall, Baton Rouge, LA 70803, USA (swarny@1su.edu) \\ ${ }^{2}$ Department of Earth Science, Rice University, 203 G Geology Building, 6100 Main Street, Houston, TX 77005, USA (johna@rice.edu) \\ ${ }^{3}$ Dépt. de Géologie et Océanographie, Université Bordeaux 1, avenue des Facultés, 33405 Talence cedex, France (1.londeix@epoc.u-bordeaux1.fr) \\ ${ }^{4}$ Department of Geology and Geophysics, Louisiana State University, E235 Howe-Russel Bldg., Baton Rouge, LA 70803, USA (pbart@geol.1su.edu)
}

\begin{abstract}
A unique reworked palynological assemblage composed of 32 to $100 \%$ (average of $63 \%$ ) in Impletosphaeridium spp., was found during the study of sixteen samples recovered from piston cores taken off Seymour Island, Antarctica, during a pre-SHALDRIL study. One of the common Impletosphaeridium species recovered, $I$. lorum, was previously found in Seymour Island's La Meseta Formation. Two questions we asked are: "What is the age of this high abundance of Impletosphaeridium spp., providing that they come from a unique source?", and second "What is the environmental significance of such a high relative abundance?" The samples are likely to have been derived from sediments ranging from Eocene to Miocene in age, as this is the range for most of the Impletosphaeridium species. The environmental significance of this high abundance is a difficult question, not only because the genus is extinct, but also because these species are poorly known. To try to understand the ecological significance, we used the hypothesis that the morphology of a dinocyst is linked to environmental sea-surface parameters, and looked at extant species with a similar morphology. The extant dinoflagellate cysts of Echinidinium spp, Islandinium cezare, Islandinium minutum, and Pentapharsodinium dalei were selected for their morphological similarity with Impletosphaeridium. Modern ecological parameters for the extant species listed above were derived from the DinoDatabase (940 modern sea-surface samples from around the world). The database showed that these species are all indicators of sea-ice cover, with a minimum of 8 months for Echinidinium spp., $\sim 5$ months for Islandinium cezare, and from 1 to 12 months for Pentapharsodinium dalei and Islandinium minutum. If our morphologic-similarity hypothesis is correct, and if this high abundance is indeed indicative of a paleo-environmental condition, then it is most likely to have been associated with ephemeral sea-ice development off Seymour Island, sometime between the Eocene and the Miocene.
\end{abstract}

Citation: Warny, S., J. B. Anderson, L. Londeix, and P. J. Bart (2007), Analysis of the dinoflagellate cyst genus Impletosphaeridium as a marker of sea-ice conditions off Seymour Island, in Antarctica: A Keystone in a Changing World - Online Proceedings of the $10^{\text {th }}$ ISAES, edited by A. K. Cooper and C. R. Raymond et al., USGS Open-File Report 2007-1047, Short Research Paper 079, 4 p.; doi:10.3133/of2007-1047.srp079

\section{Introduction}

Conducting palynological investigations in Antarctica is one of the key elements in understanding past Antarctic climate and specifically, how it evolved from greenhouse to icehouse conditions. Fossils of pollen grains are excellent for reconstructing past vegetation, hence climate, while dinoflagellate cysts are useful proxies for reconstructing sea-surface conditions (Troedson and Riding, 2002). For instance, Mao and Mohr (1995), thanks to exceptionally rich dinocyst assemblages from Bruce Bank, were able to estimate winter surface water paleotemperatures at about $5^{\circ}$ to $10^{\circ} \mathrm{C}$ and summer temperatures reaching more than $14^{\circ} \mathrm{C}$ for the Neogene climatic optimum. Marret and de Vernal (1997) described a diverse modern Antarctic palynoflora from the southern Indian Ocean (south of Australia) with a distribution linked to temperature and salinity. Harland and Pudsey (1999) demonstrated the existence of two modern, distinct dinocyst communities, on both sides of $60^{\circ} \mathrm{S}$ latitude, along a transect from Argentina to the Weddell Sea. They presented a modern dinocyst distribution clearly linked to sea-ice extent, demonstrating that the maximal extent of the northern winter limit of sea-ice cover is a major controlling parameter in dinocyst distribution. The reconstruction of sea-ice cover evolution, based on marine-palynomorph distribution is possibly the area with the highest potential for new palynological concepts and impact for the Antarctic community. In situ sections such as those obtained via CRP (Cape Roberts Project), ANDRILL (ANtarctic geological DRILLing), and SHALDRIL (SHALlow DRILling Project) technology are the most desirable sections to conduct palynology, but these sites are still too few. In order to prepare for the study of SHALDRIL cores, we analyzed the sediments recovered by piston cores drilled in the SHALDRIL target areas to evaluate the chance of microfossil recovery. The main focus of this paper is to evaluate the environmental significance of the unique dinoflagellate-cyst assemblage recovered in these piston cores, and analyze whether or not these cysts can provide proof of a semi-permanent sea-ice cover that would have existed on the Antarctic Peninsula.

\section{Material and methods}

A detailed palynological analysis of sixteen samples collected from seven piston cores acquired along two transects off Seymour and James Ross Islands was conducted (Figure 1). Five locations sampled by the Glacier DF82 campaign, including PC192 (A: 3 samples), PC174 (B: 3 samples), PC1 (C: 3 samples), PC20 (D: 2 samples), and PC28 (G: 2 samples); and two locations sampled during the Nathaniel B. Palmer 
campaign NBP02-01, including sites PC3 (E: 1 sample), and PC6 (F: 2 samples), were studied.

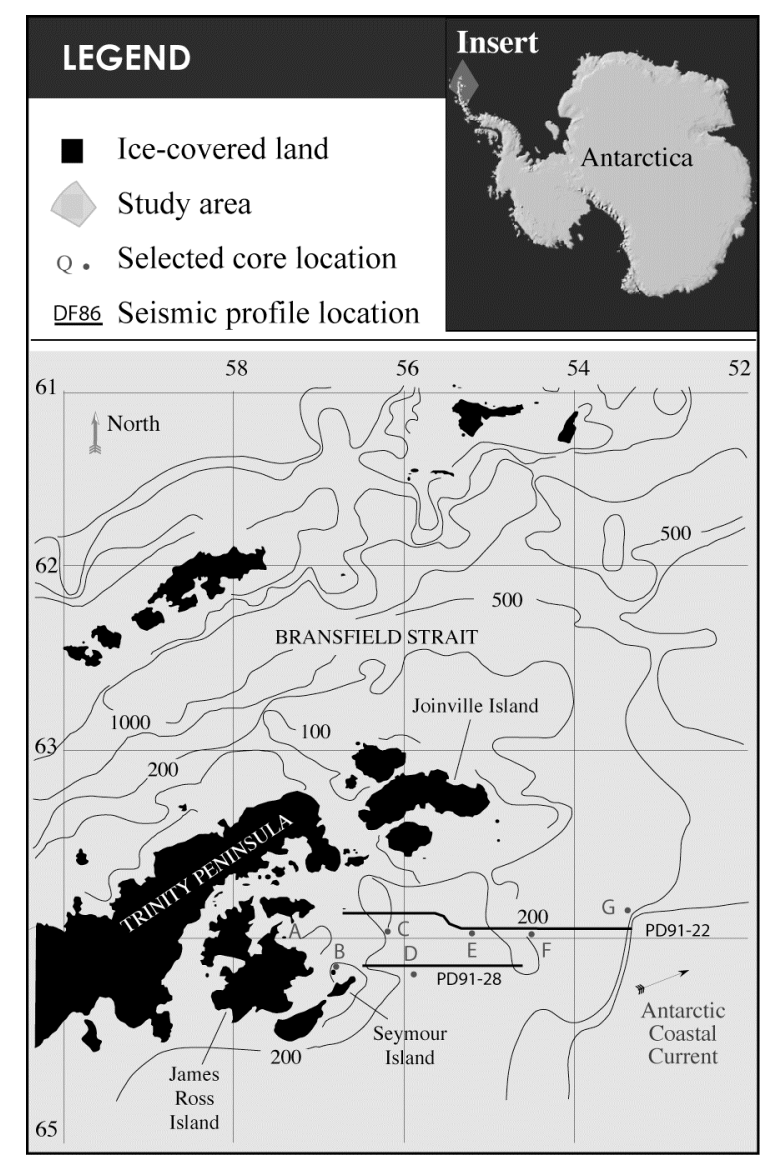

Figure 1. Bathymetric map of the Antarctic Peninsula showing location of selected cores.

These piston cores sampled strata immediately offshore and down dip of Seymour Island (Figure 1). These core locations were selected specifically because seismic profiles show a series of basinward tilted sedimentary deposits truncated at or near the seafloor. These strata are estimated to range from upper Eocene to upper Neogene in age (Anderson, 1999). Recent glacial erosion has "exposed" virtually the entire stratigraphic section below the thin glacial unit deposited at the seafloor. It is assumed that the buried sections were sampled by the ice sheet as it advanced across the shelf. We hypothesized that, thus, the glacial sediments sampled by the piston cores should include reworked palynomorphs from the underlying stratigraphic section.

The processing method followed is a typical palynological technique. Ten grammes of dried sample were weighed and spiked with a known quantity of Lycopodium spores to allow computation of the absolute abundance of palynomorphs in the sample. Acid soluble minerals were digested in a Prolabo M-401 focused microwave digestion unit. The palynomorphs were then concentrated by filtration on a ten-micron mesh sieve.
Because of the low concentration of palynomorphs recovered (typical of Antarctic sediments sampled at a latitude higher than $60^{\circ} \mathrm{S}$ ), one hundred palynomorphs were counted when possible to provide age and paleoenvironmental determinations. A database of the palynomorphs was prepared and key species were photographically documented.

\section{Palynological results}

All samples analyzed are composed of glaciomarine sediments and contained primarily reworked material ranging from Maastrichtian to Oligocene (and possibly Miocene) in age.

The main terrestrial palynomorphs recovered include several trilete and monolete spores, such as Cyathidites minor, Laevigatosporites major, Laevigatosporites ovatus, Polypodiisporites radiatus, and Stereisporites antiquasporites. They also include the gymnosperm pollen Podocarpidites spp. Angiosperm pollen recovered are composed of various species of Nothofagidites, including $N$. flemingii, and $N$. lachlaniae, various species of Tricolpites, Periporopollenites sp., Proteacidites sp., Peninsulapollis askiniae, Peninsulapollis gillii and members of the Ericaceae and Rubiaceae families.

The marine assemblage is mainly characterized by dinoflagellate cyst and acritarch species, along with rare occurrences of leiospheres and foraminifer linings. Some of the main cysts recovered include species from the genus Manumiella, such as Manumiella delicata, Manumiella druggii, Manumiella sp. 1 of Askin 1988, and Manumiella seymourensis. Rare specimens of Operculodinium bergmannii, Operculodinium centrocarpum, Spinidinium lanternum and Vozzhennikovia apertura were also recovered. The bulk of this assemblage is composed of up to $17 \%$ of species of Palaeostomocystis (Warny, submitted), and of 32 to $100 \%$ of species belonging to the genus Impletosphaeridium. Indeed, these Impletosphaeridium species make up an average of $63 \%$ of the reworked marine palynomorphs for all samples. The most common species found is Impletosphaeridium lorum. The other Impletosphaeridium species recovered are believed to be closely related to this species but have not yet been described. They mainly differ from each other by the thickness of their processes. But the overall dinoflagellate cyst morphology and their overall size are very similar.

\section{Discussion on ecology}

A qualitative analysis of the abundance of dinoflagellate cysts, and specifically, the unusual abundance in Impletosphaeridium species, was undertaken to evaluate any potential environmental significance. The fact that most palynomorphs recovered are reworked is a limiting factor. Nevertheless, such a strong relative abundance in a reworked genus may indicate that the source of these reworked palynomorphs 


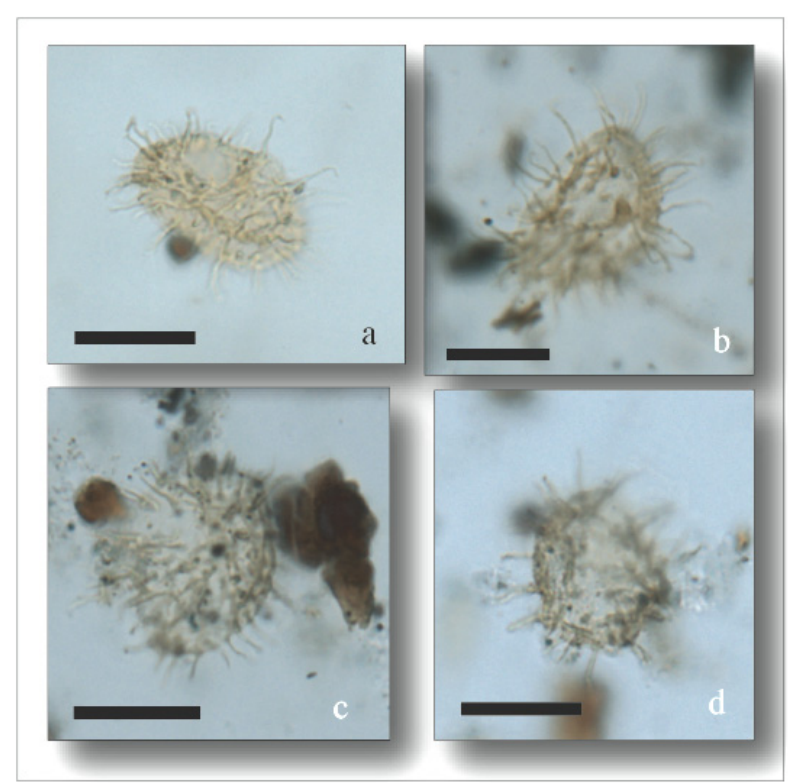

Figure 2. Photomicrographs of selected species of Impletosphaeridium recovered from this project (scale bar $=20$ microns). a. Impletosphaeridium sp., core DF $82 / \mathrm{PC} 20 / 289 \mathrm{~cm}$, coordinate $14 \times 141$. b. $I$. sp., core $\mathrm{DF} 82 / \mathrm{PC} 28 / 223 \mathrm{~cm}$, coordinate $17.8 \times 149.5$. c. $I$. sp., core NBP02-01/PC06/37 cm, coordinate 10x143.4. d. $I$. sp., core NBP02-01/PC06/37 cm, coordinate $6.2 \times 134$.

is nearby. Furthermore, monospecific assemblages or assemblages with a strong dominance in a specific genus, are often indicative of specific environmental conditions or abrupt environmental changes, changes to which only a few species could adapt.

During this evaluation, two questions were asked:

a) What is the possible age of this abundance?

b) What is its environmental significance?

Concerning the age, we believe that the abundance of Impletosphaeridium species must have occurred between the Eocene and Miocene as most species of this genus have ranges that span between the Eocene and the Miocene. Based on the similarity between I. lorum in our samples and those described from Seymour Island's La Meseta Formation as Eocene (Wrenn and Hart, 1988), an Eocene age for this "influx" is possible. This said, very little material of Oligocene age was recovered from this section, so a younger age is also possible.

The environmental significance is a difficult question as well because:

a) the genus is extinct, therefore, the ecology of this group is uncertain,

b) such a high abundance of Impletosphaeridium has never been described before, and

c) Impletosphaeridium species are difficult to differentiate reliably to the species level. Palynologists have taken two approaches over the years: one is to split them into various species, with the risk of over-splitting and then describing new species based on transitional morphological features; the second is to lump them into the smallest group possible - which is the approach taken here.

In order to evaluate Impletosphaeridium's ecological affinity, we analyzed a presumed morphological convergence, in other words, we used the similarities of these extinct species with those of modern species that have known ecological significance. Indeed, it has been proven that environmental characteristics influence the overall morphology of dinoflagellate cysts, and thus, morphology is believed to be partly controlled by factors such as sea-surface salinity and temperature. Using this approach, we selected a series of modern species based on their strong morphological similarities with Impletosphaeridium lorum and Impletosphaeridium $\mathrm{sp} . \mathrm{B}$ of Wrenn and Hart (1988), both originally described from La Meseta Formation, the Eocene formation exposed on Seymour Island. The extant cysts selected as modern analogues are Echinidinium spp., Islandinium cezare, Islandinium minutum, and Pentapharsodinium dalei. Londeix provided ecological parameters for the modern species based on data archived in the DinoDatabase, a database composed of 940 modern sea-surface samples from around the world (e.g., de Vernal et al., 2001; 2005). The database shows a strong correlation between extant species and sea-ice cover (Figure 3). Out of all the dinoflagellates present in world oceans, the morphologically-similar species are all indicators of seaice cover, with a minimum of 8 months for Echinidinium spp., $\sim 5$ months for Islandinium cezare, and from 1 to 12 months for Pentapharsodinium dalei and Islandinium minutum.

In short, these morphologically similar extant species are abundant today in oceans characterized by one to nine months of ephemeral sea-ice cover. Therefore, we postulate that the dominance in Impletosphaeridium species might be the first evidence recorded by phytoplankton of sea-ice cover off Seymour Island between the Eocene and Miocene.

\section{Conclusions}

Species of Impletosphaeridium are the dominant forms of marine microfossils in the samples studied. One of them, I. lorum is similar to the species reported from the Eocene La Meseta Formation from Seymour Island (Wrenn and Hart, 1988). Morphologically similar extant species are abundant today in oceans characterized by one to nine months of sea-ice cover. If our morphological similarity hypothesis is correct, this abundance of Impletosphaeridium spp. is the first major dinoflagellate event marking the onset of Antarctic sea-ice development off Seymour Island, possibly at the end of the Eocene epoch, if the species were deposited in layers that are ageequivalent to the La Meseta Formation. The reworked nature of sediment and the lack of well-documented last appearance datums for these species prevent us of providing a minimum age for the observed abundances. 

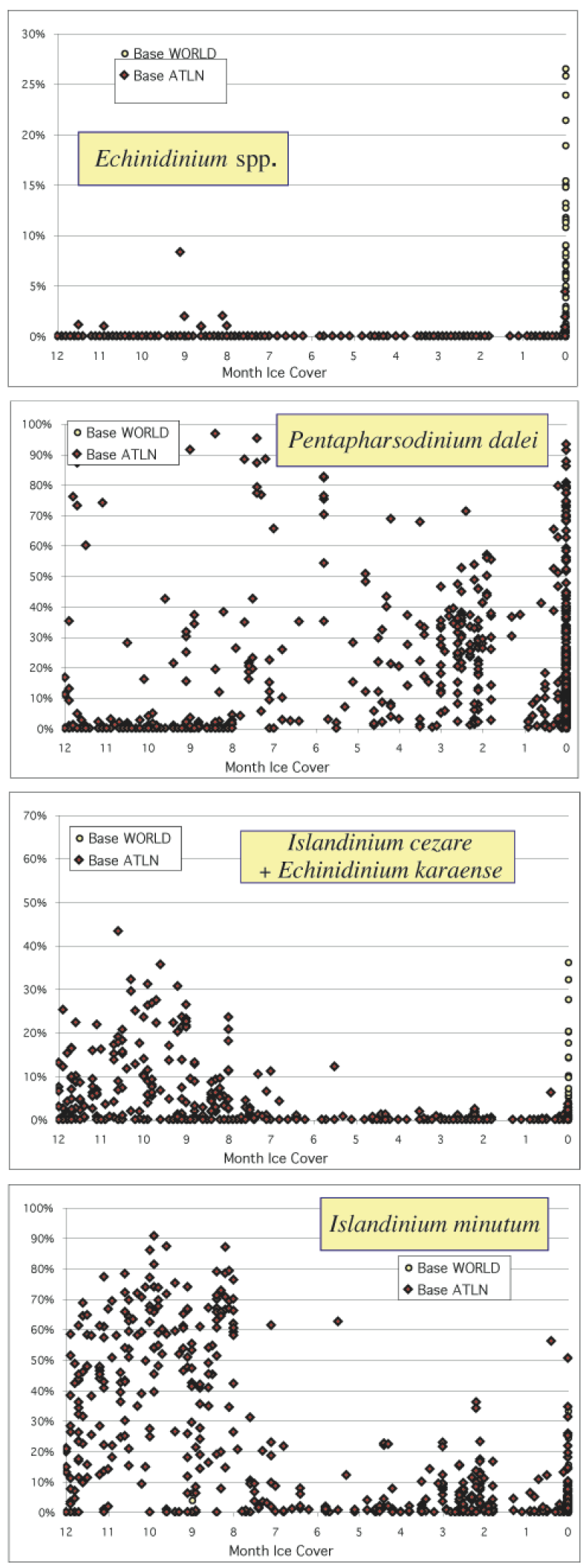

Figure 3. Modern relative abundance of selected dinoflagellate cyst species against months of sea-ice cover (created from the DinoDatabase, $n=940$ ).
Our future goal is to use the recently-acquired SHALDRIL in situ material, to hopefully constrain the onset of declining sea-surface temperatures and associated ephemeral sea-ice cover. We hope to correlate the evolution of sea-ice cover on the Antarctic Peninsula to the establishment of a full-bodied ice sheet in Antarctica (Anderson, 1999) and major global cooling (Zachos et al., 2001).

Acknowledgements. We thank the reviewers for helping us improve this manuscript. Our most sincere gratitude is extended to the National Science Foundation for funding this research (SGER grant \#0533879). Thanks are also extended to the Antarctic Research Facility staff for assisting us with our sampling needs.

\section{References}

Anderson, J. B. (1999), Antarctic Marine Geology. Cambridge University Press. Cambridge.

Askin, R. A. (1988), Campanian to Paleocene palynological succession of Seymour and adjacent islands, northeastern Antarctic Peninsula. Geol. Soc. Am. Mem., 169, 131-154.

de Vernal A., M. Henry, J. Matthiessen, P. J. Mudie, A. Rochon, K. Boessenkool, F. Eynaud, K. Grøsfjeld, J. Guiot, D. Hamel, R. Harland, M. J. Head, M. Kunz-Pirrung, E. Levac, V. Loucheur, O. Peyron, V. Pospelova, T. Radi, J. L. Turon, and E. Voronina (2001), Dinocyst assemblages as tracer of sea-surface conditions in the northern North Atlantic, Arctic and sub-Arctic seas: the " $\mathrm{n}=677$ " database and derived transfer functions. J. Quat. Sci., 16, 681-698.

de Vernal A., F. Eynaud, M. Henry, C. Hillaire-Marcel, L. Londeix, S. Mangin, J. Matthiessen, F. Marret, T. Radi, A. Rochon, S. Solignac, and J. L. Turon (2005), Reconstruction of sea-surface conditions at middle to high latitudes of the Northern Hemisphere during the Last Glacial Maximum (LGM) based on dinoflagellate cyst assemblages. Quat. Sci. Rev., 24, 897-924.

Harland, R., and C. J. Pudsey (1999), Dinoflagellate cysts from sediment traps deployed in the Bellinghausen, Weddell and Scotian Seas, Antarctica. Mar. Micropaleont., 37, 77-99.

Mao, S., and B. A. R. Mohr (1995), Middle Eocene dinocysts from Bruce Bank (Scotia Sea, Antarctica) and their paleoenvironmental and paleogeographic implications. Rev. Palaeobot. Palynol., 86, 235263.

Marret, F., and A. de Vernal (1997), Dinoflagellate cyst distribution in surface sediments of the southern Indian Ocean. Mar. Micropaleont., $29,367-392$.

Troedson A. L., and J. B. Riding (2002), Upper Oligocene to lowermost Miocene strata of King George Island, South Shetland Islands, Antarctica: stratigraphy, facies analysis, and implications for the glacial history of the Peninsula. J. Sed. Res., 72(4), 510-523.

Warny, S., submitted. Palaeostomocystis spp.: A potential indicator of neritic subpolar environments in Antarctica. Palynology.

Wrenn, J. H., and G. F. Hart (1988), Paleogene dinoflagellate cyst biostratigraphy of Seymour Island. Geol. Soc. Mem., 169, 321-448.

Zachos, J., M. Pagani, L. Sloan, E. Thomas, and K. Billups (2001), Trends, rhythms, and aberrations in global climate $65 \mathrm{Ma}$, to present. Science, 292, 686-693. 